\title{
RADIOCARBON AND STABLE ISOTOPE ANALYSES ON THE EARLIEST JOMON SKELETONS FROM THE TOCHIBARA ROCKSHELTER, NAGANO, JAPAN
}

\author{
Minoru Yoneda ${ }^{1,2} \bullet$ Masashi Hirota ${ }^{3} \bullet$ Masao Uchida $^{4} \bullet$ Atsushi Tanaka ${ }^{1}$ Yasuyuki Shibata $^{1} \bullet$ \\ Masatoshi Morita $^{1} \cdot$ Takeru Akazawa ${ }^{5}$
}

\begin{abstract}
This study presents the results of carbon and nitrogen isotopic analyses of six human skeletons excavated from the Tochibara rockshelter (Nagano, Japan). The human skeletons were reported to be accompanied by "Oshigata-mon" type pottery dating to the Earliest Jomon period $(8900 \mathrm{BP} \sim 6600 \mathrm{BP})$. A radiocarbon determination from charcoal associated with the human remains was reported to be $8650 \pm 180 \mathrm{BP}(\mathrm{GaK}-1056)$. However, the depositional context of human skeletons was uncertain because they were recovered by excavations that were dug by prescribed levels. Our results indicated that these skeletons date to the Earliest Jomon period; the ${ }^{14} \mathrm{C}$ determinations place these remains between $8260 \pm 100$ BP (TERRAb030799ab38) and $8580 \pm 100 \mathrm{BP}$ (TERRA-b011300a35). This coincides with the archaeological evidence that these specimens are some of the oldest Jomon skeletal materials. Furthermore, $\delta^{13} \mathrm{C}$ and $\delta^{15} \mathrm{~N}$ values provide evidence for the first reconstruction of the diet of an inland Earliest Jomon population. Although the distribution of data indicated a possibility that they had exploited small amounts of seafood, the isotopic data point to this group having relied heavily on a terrestrial ecosystem based on $\mathrm{C}_{3}$ plants.
\end{abstract}

\section{INTRODUCTION}

In the present study, we re-evaluated the skeletal specimens recovered from the Tochibara rockshelter by measuring the carbon and nitrogen isotopes in six human remains. Radiocarbon $\left({ }^{14} \mathrm{C}\right)$ dating and dietary reconstruction based on stable carbon and nitrogen isotopes were done.

This skeletal collection from the Tochibara site is representative of an inland population dating to the Earliest Jomon period. From this site, 12 skeletons including two infants and two children were recovered (Kohara et al. 1971; Nishizawa 1978). Two children are suspected to have been killed by a rock fall accident since they were found beneath a fallen rock in the position for running. It is thought to be the oldest evidence of a fatal accident in Japan (Kohara et al. 1971). In the case of the inland Japan, well-preserved human skeletons are very rare because of the soil acidity. Hence, the human skeletons from the Tochibara rockshelter are important for the investigation of morphological characteristics of the Earliest Jomon people residing in the inland region.

However, the depositional context of human remains was not fully defined during the excavation. The site consists of superimposed layers from the Earliest Jomon through Yayoi periods. Stratigraphic data on each individual remain have not been certified since excavations were conducted by the arbitrary level method digging in steps of $10 \mathrm{~cm}$ deep, not by following the natural layers of deposit. Previous studies have reported three ${ }^{14} \mathrm{C}$ ages of charcoals at different levels (Nishizawa 1982); $7920 \pm 80 \mathrm{BP}(\mathrm{GaK}-1054), 8650 \pm 180 \mathrm{BP}(\mathrm{GaK}-1056)$, and $8870 \pm 220 \mathrm{BP}(\mathrm{GaK}-3773)$. Re-excavations showed that stratigraphic structure of this site was very complex (Oomi 1984), and it has become more important to evaluate the original period of human specimens exactly. Hence, it was aimed in the present study to determine the ${ }^{14} \mathrm{C}$ ages on human remains directly by using the accelerator mass spectrometry (AMS). The chronological placement of this skeletal collection is essential when investigating its anthropological traits, and studying it in terms of regional and temporal variations among the Jomon.

${ }^{1}$ Environmental Chemistry Division, National Institute for Environmental Studies, Onogawa 16-2, Tsukuba, Ibaraki 305 8506, Japan

${ }^{2}$ Corresponding author. Email: myoneda@nies.go.jp.

${ }^{3}$ Institute of Accelerator Analysis, Ltd. Ichiridan 6-270, Shirasaka, Shirakawa, Fukushima 961-0835, Japan

${ }^{4}$ Japan Marine Science and Technology Center, Natsushima-cho 2-15, Yokosuka, Kanagawa 237-0061, Japan

${ }^{5}$ International Research Center for Japanese Studies, Oeyama-cho 3-2, Goryo, Nishikyo-ku, Kyoto 610-1192, Japan 
At the same time, stable isotopes of carbon and nitrogen in preserved protein, collagen, can reveal aspects of their dietary habits. Based on isotopic analyses and other archaeological evidence, it has been revealed that the Jomon people were hunter-gatherer-fishers adapting themselves to regional circumstances (Minagawa and Akazawa 1992). However, almost all data for discussion so far have been obtained from coastal populations found in Jomon shell middens. This study presents the first quantitative evaluation on the dietary habits of the inland Earliest Jomon people.

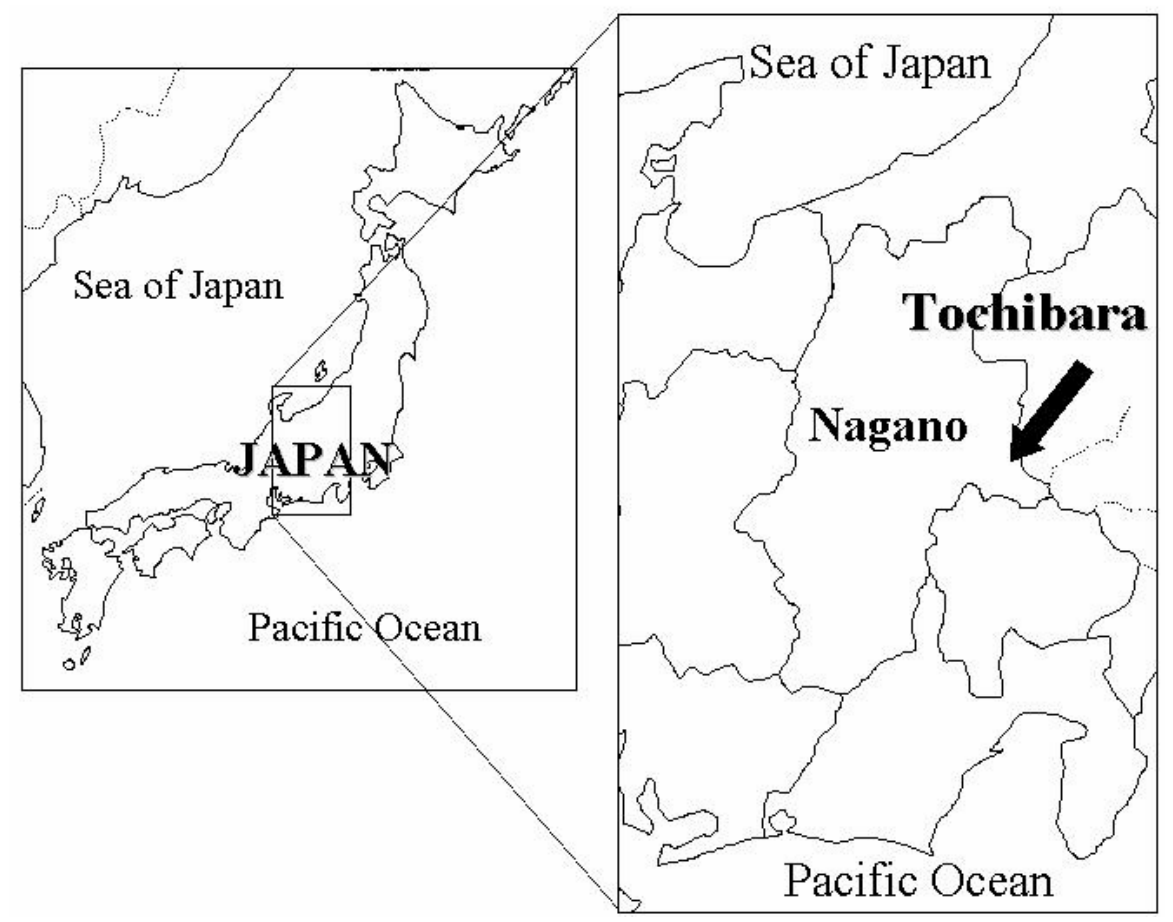

Figure 1 Location of the Tochibara rockshelter, Nagano prefecture, Japan

\section{MATERIALS AND METHODS}

The Tochibara rockshelter is located in Kita-Aiki village, Minami-Sakuma county, Nagano prefecture (Figure 1). The rockshelter lies on a palisade facing the Aiki river. In 1965, the first skeleton (KA-1) was found and excavations were then conducted 15 times by Professor M Suzuki of the Department of Medicine, Shinshu University, and his colleagues until 1978 (Oomi 1984). Excavations revealed human skeletons of eight adults, two children, and two infants. As mentioned above, the two children (KA-11 and KA-12) are thought to have been killed by a rockfall (Kohara et al. 1971). The morphological characteristics of the eight adults were reported (Nishizawa 1978). Furthermore, a large amount of artifacts was recovered from deposits believed to date between the Earliest Jomon through the Yayoi period. Most layers yielded the Earliest Jomon pottery. The human remains were accompanied by the "Oshigata-mon" type pottery of the Earliest Jomon period. The typical ${ }^{14} \mathrm{C}$ age for this cultural period is between 8900 BP and 6600 BP in Nagano (Kawasaki 1997).

In this study, six individuals were analyzed for ${ }^{14} \mathrm{C}$ age, $\delta^{13} \mathrm{C}$, and $\delta^{15} \mathrm{~N}$ values. KA-1 individual is one of the oldest Jomon people that has a complete facial cranium. KA-1, KA-2, KA-4, and KA-7 were buried closely in the center of the terrace, which were found in the arbitrary level between $-150 \mathrm{~cm}$ 
and $-200 \mathrm{~cm}$ from the surface (see Table 1). For this level, ${ }^{14} \mathrm{C}$ dating of charcoal fragments excavated at a depth of $-150 \mathrm{~cm}$ to $-182 \mathrm{~cm}$ gave a date of $8650 \pm 180 \mathrm{BP}(\mathrm{GaK}-1056)$, but this date has not been corrected for isotopic fractionation (Kunihiko Kigoshi, personal communication). On the other hand, KA-8 was not found in the same area as the four burials, but at the eastern edge of the terrace, and its stratigraphic level and depth were also different, $-211 \mathrm{~cm}$. KA-10 was found at the next rockshelter to the east of the main shelter. Even if the burial deposit was primary without any postdepositional disturbance, the correspondence between charcoal ages and skeleton ones has not been confirmed, especially in the cases of KA-8 and KA-10.

Table 1 List of the Tochibara rockshelter specimens analyzed in this study

\begin{tabular}{lllcc}
\hline Sample nr & Sex & Age & $\begin{array}{c}\text { Excavated } \\
\text { level }\end{array}$ & $\begin{array}{c}\text { Excavation } \\
\text { year }\end{array}$ \\
\hline KA-1 & Male & Adult & $-155 \mathrm{~cm}$ & 1965 \\
KA-2 & Male & Adult & $-201 \mathrm{~cm}$ & 1965 \\
KA-4 & Female & Adult & $-173 \mathrm{~cm}$ & 1965 \\
KA-7 & Female & Adult & No data & 1966 \\
KA-8 & Female & Adult & $-211 \mathrm{~cm}$ & 1966 \\
KA-10 & Female & Adult & No data & 1967 \\
\hline
\end{tabular}

For ${ }^{14} \mathrm{C}$ dating, AMS measurement requires a smaller amount of sample (ca. $1 \mathrm{mg}$ of carbon) than the conventional $\beta$ counting method, since it counts the exact number of ${ }^{14} \mathrm{C}$ atoms. Because of this technical development, it has become possible to measure the ${ }^{14} \mathrm{C}$ age of human bone material without seriously damaging the fossil hominid specimen. Typically, bone pieces of $0.5 \sim 1.0 \mathrm{~g}$ were taken from a rib bone or other useless bone element. Then the inorganic part was removed by $1 \mathrm{~N}$ hydrochloric acid. From the remaining organic matter, the collagen was extracted and purified by the gelatinization method improved from Longin's (1971). The detailed procedure was described elsewhere (Yoneda et al. 1996).

The extracted collagen was analyzed for carbon and nitrogen contents in order to investigate contamination of the extracted collagen. An elemental analyzer (EA; Calro Erba NA 1500, CE Elantech, Inc, Lakewood, New Jersey, USA) was employed, which is combined to an isotope ratio mass spectrometry (IRMS; MAT252, Thermo Finnigan MAT GmbH, Bremen, Germany), for both the elemental analyses and the preparation for isotope analyses. Typically, $0.25 \mathrm{mg}$ of collagen was combusted in the EA and the resulting $\mathrm{CO}_{2}$ and $\mathrm{N}_{2}$ were introduced to the IRMS for measuring ${ }^{13} \mathrm{C} /$ ${ }^{12} \mathrm{C}$ and ${ }^{15} \mathrm{~N} /{ }^{14} \mathrm{~N}$. The isotope ratios were usually shown in the $\delta$ values in comparison with standard materials, PDB for carbon and AIR for nitrogen. The uncertainty with this system was estimated around $0.25 \%$ or $\delta^{15} \mathrm{~N}$ and $0.10 \%$ for $\delta^{13} \mathrm{C}$.

Then, $2.5 \mathrm{mg}$ of collagen was converted to graphite with iron catalysis for the ${ }^{14} \mathrm{C}$ analysis (Kitagawa et al. 1993). Pretreatment of samples, graphitization and ${ }^{14} \mathrm{C}$ measurements were conducted at NIES-TERRA (Tanaka et al. 2000). At least two kinds of standard materials were loaded with unknown samples contemporaneously to calibrate the measured ${ }^{14} \mathrm{C} /{ }^{12} \mathrm{C}$. The new oxalic acid (NBS RM-4990C), IAEA standard materials, such as C6 (ANU sucrose) and C7 were employed. For each ${ }^{14} \mathrm{C}$ determination, measurements were taken for 10 minutes and repeated three times.

\section{RESULTS}

Table 2 shows the results on stable isotopic and elemental analyses. The $\mathrm{C} / \mathrm{N}$ ratio is employed to certify the purity of extracted gelatin. If a $\mathrm{C} / \mathrm{N}$ ratio did not show a value between 2.9 and 3.6, the 
gelatin might be contaminated with foreign organic matter (DeNiro 1985). However, in all the Tochibara samples, the $\mathrm{C} / \mathrm{N}$ showed reasonable values as pure collagen. Based on this datum, we concluded that the extracted materials principally consist of collagen and that the results of $\delta^{13} \mathrm{C}$, $\delta^{15} \mathrm{~N}$ values, and ${ }^{14} \mathrm{C}$ ages are reliable as the biogenic signals and their original ages without diagenetic effects.

Table 2 Stable isotopic ratios, carbon and nitrogen concentrations, and $\mathrm{C} / \mathrm{N}$ ratios in collagen extracted from human remains from the Tochibara rockshelter

\begin{tabular}{lccccc}
\hline Sample nr & $\delta^{13} \mathrm{C}(\% \circ)$ & $\delta^{15} \mathrm{~N}(\% \circ)$ & $\mathrm{C}(\%)$ & $\mathrm{N}(\%)$ & $\mathrm{C} / \mathrm{N}$ ratio \\
\hline KA-1 & -19.7 & 7.7 & 43.1 & 15.1 & 3.34 \\
KA-2 & -20.4 & 6.0 & 44.9 & 16.2 & 3.23 \\
KA-4 & -19.7 & 7.6 & 45.1 & 15.8 & 3.33 \\
KA-7 & -19.8 & 7.1 & 46.2 & 16.2 & 3.33 \\
KA-8 & -19.8 & 6.9 & 46.0 & 16.7 & 3.21 \\
KA-10 & -19.8 & 7.4 & 45.3 & 16.5 & 3.21 \\
\hline
\end{tabular}

Their protein sources were estimated by comparing the isotopic values of nutritional groups and the estimated values of dietary protein. Figure 2 shows the isotopic values of typical native foodstuff collected in the Japanese archipelago and the North Pacific (Shimojo 1988; Welch and Parsons 1993; Minami 1995) and reconstructed values of muscle from archaeological mammals (Yoneda unpublished data). As shown in the figure, the source data can be divided into six groups. In general, bone collagen is enriched $+4.5 \%$ for $\delta^{13} \mathrm{C}$ and $+3.5 \%$ for $\delta^{15} \mathrm{~N}$ in comparison with average of absorbed protein, respectively (Ambrose 1993). In Figure 3, the results of human protein sources were plotted in the region of $\mathrm{C}_{3}$ plants and its consumer. It is clear that they lived on terrestrial foods as main protein sources and it is reasonable that the inland Jomon hunter-gatherer adapted to the terrestrial circumstance.

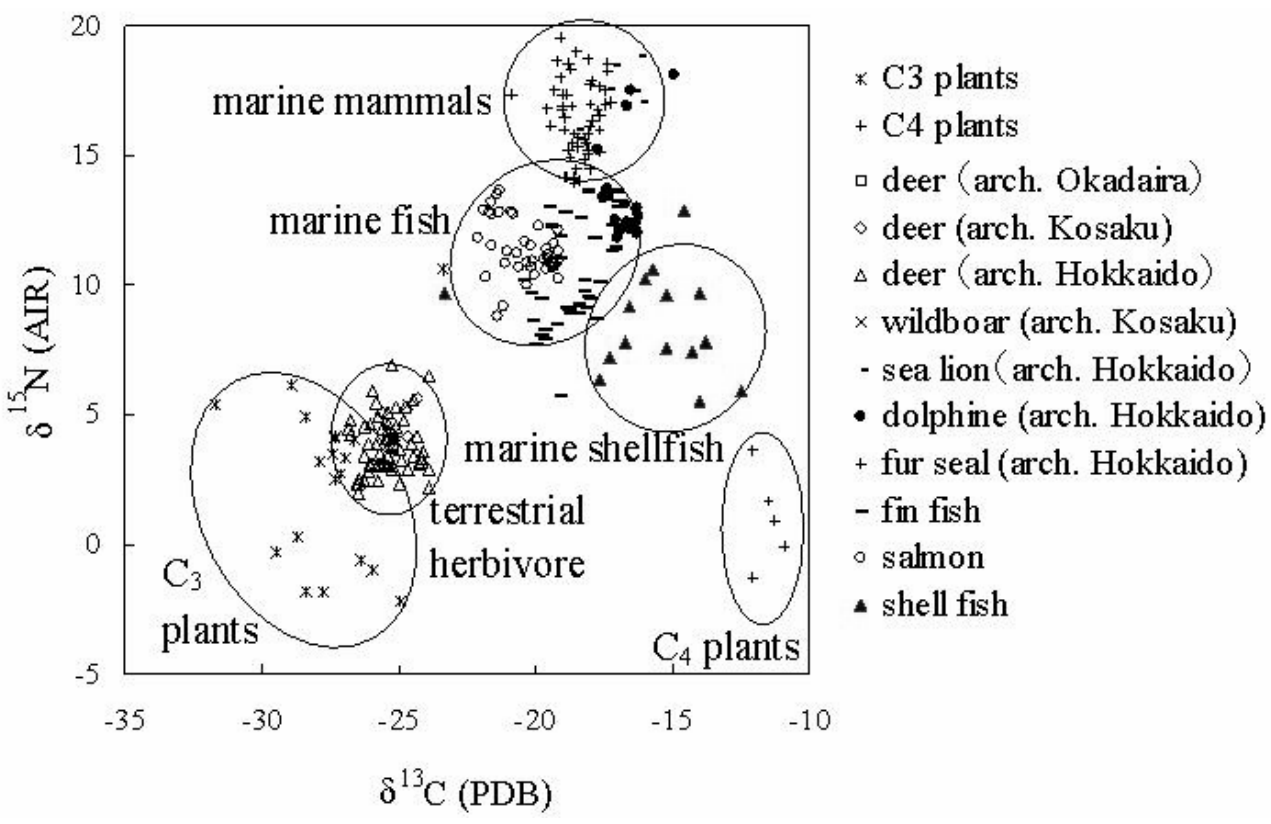

Figure 2 Typical isotopic values of Japanese native foodstuff. For details, see the text. 
However, a clear correlation $(\mathrm{r}=0.936)$ observed between $\delta^{13} \mathrm{C}$ and $\delta^{15} \mathrm{~N}$ in human collagen suggests that they exploited two kinds of protein sources dominantly (see Figure 3), and these end-points of the regression line should suggest these two sources theoretically (Schwarcz 1991). In the case of the Tochibara site, it is possible that $\mathrm{C}_{3}$ plants and terrestrial herbivore are suggested on one end, and marine fish and marine mammals on the other. It is likely that they have exploited some amount of seafood in their daily diet, because faunal remains include chum salmon (Oncorhynchus keta) and/or cherry salmon (Oncorhynchus masou) and other marine organisms, but the amount of seafood should have been very limited. Furthermore, it is difficult to discriminate the results between plants and herbivore, because the mixture of $\mathrm{C}_{3}$ plants and seafood yielded the same isotopic features apparently as the terrestrial mammal from the isotopic point of view. That is why we did not try quantitative reconstruction of the prehistoric diet in the present study. Nevertheless, it is possible to say that the reconstructed human diet relied mainly on the protein originating from the terrestrial ecosystem.

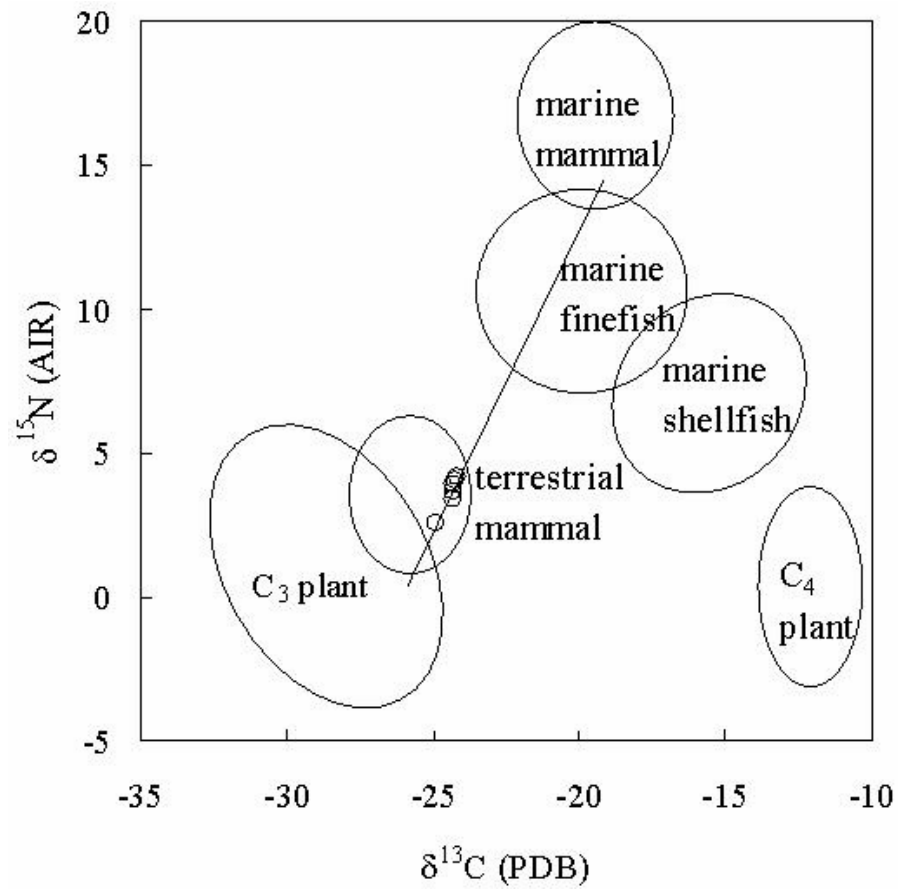

Figure 3 Carbon and nitrogen isotope ratios of the exploited protein by the Tochibara people. Significant correlation is observed between $\delta^{13} \mathrm{C}$ and $\delta^{15} \mathrm{~N}$ values.

Table 3 shows the result of ${ }^{14} \mathrm{C}$ determinations on human bones excavated form the Tochibara rockshelter. The $1 \sigma$ error is cited. They were buried between $8300 \mathrm{BP}$ to $8600 \mathrm{BP}$, which coincides with the archaeological materials and the previous ${ }^{14} \mathrm{C}$ determination. However, the burials were not contemporary with one another. Even in the case of KA-1, KA-2, and KA-4, which are associated with each other, the three ${ }^{14} \mathrm{C}$ determinations span over $200{ }^{14} \mathrm{C}$ yr. However, it seems reasonable amongst the three skeletons, that KA-1 $(8370 \pm 70 \mathrm{BP})$, with the highest elevation is slightly younger than KA-2 $(8580 \pm 100 \mathrm{BP})$ and KA-4 $(8530 \pm 80 \mathrm{BP})$, which are from deeper levels (see Table 1). Although KA-8 was found from the deeper level $(-211 \mathrm{~cm})$, its ${ }^{14} \mathrm{C}$ age $(8300 \pm 80 \mathrm{BP})$ was similar to KA-1 and younger than KA-2 and KA-4. This discrepancy suggests that the stratigraphic layers 
declined towards the shelter's opening, and that the elevations at the different positions did not correspond to each other. On the other hand, KA-10 who was found from the different shelter yielded a similar result as others, suggesting that this individual also dates to the Earliest Jomon period and might belong to the same population.

Table 3 Conventional and calibrated ${ }^{14} \mathrm{C}$ ages of the Tochibara specimens

\begin{tabular}{|c|c|c|c|c|c|c|c|c|}
\hline \multirow{2}{*}{$\begin{array}{l}\text { Sample nr } \\
\text { KA-1 }\end{array}$} & \multirow{2}{*}{$\begin{array}{l}\text { Code nr } \\
\text { TERRA-b030799ab17 }\end{array}$} & \multicolumn{3}{|c|}{$\begin{array}{c}\text { Conventional }{ }^{14} \mathrm{C} \\
\text { age }(\mathrm{BP} \pm 1 \sigma)\end{array}$} & \multicolumn{3}{|c|}{$\begin{array}{l}\text { Calibrated age } \\
\text { (cal BP) }\end{array}$} & \multirow{2}{*}{$\frac{\text { Probability }}{68.2 \%}$} \\
\hline & & 8370 & \pm & 70 & 9490 & - & 9280 & \\
\hline KA-2 & TERRA-b011300a35 & 8580 & \pm & 100 & 9690 & - & 9470 & $68.2 \%$ \\
\hline KA-4 & TERRA-b030799ab26 & 8530 & \pm & 80 & $\begin{array}{l}9560 \\
9450\end{array}$ & $\begin{array}{l}- \\
-\end{array}$ & $\begin{array}{l}9470 \\
9440\end{array}$ & $\begin{array}{r}65.4 \% \\
2.8 \%\end{array}$ \\
\hline KA-7 & TERRA-b030799ab27 & 8430 & \pm & 70 & $\begin{array}{l}9530 \\
9410 \\
9340\end{array}$ & $\begin{array}{l}- \\
- \\
-\end{array}$ & $\begin{array}{l}9420 \\
9400 \\
9330\end{array}$ & $\begin{array}{r}62.7 \% \\
2.3 \% \\
3.2 \%\end{array}$ \\
\hline KA-8 & TERRA-b030799ab28 & 8300 & \pm & 80 & $\begin{array}{l}9470 \\
9430 \\
9180\end{array}$ & $\begin{array}{l}- \\
- \\
-\end{array}$ & $\begin{array}{l}9450 \\
9250 \\
9130\end{array}$ & $\begin{array}{r}3.2 \% \\
55.8 \% \\
9.1 \%\end{array}$ \\
\hline KA-10 & TERRA-b030799ab38 & 8260 & \pm & 100 & $\begin{array}{l}9420 \\
9330 \\
9110\end{array}$ & $\begin{array}{l}- \\
- \\
-\end{array}$ & $\begin{array}{l}9340 \\
9120 \\
9090\end{array}$ & $\begin{array}{r}16.2 \% \\
49.6 \% \\
2.4 \%\end{array}$ \\
\hline
\end{tabular}

\section{DISCUSSION}

In a previous paper, three ${ }^{14} \mathrm{C}$ ages of charcoal samples were reported; $7920 \pm 80 \mathrm{BP}, 8650 \pm 180 \mathrm{BP}$, and $8870 \pm 220 \mathrm{BP}$ at $-95 \sim-127 \mathrm{~cm},-150 \sim-182 \mathrm{~cm}$, and $-534 \sim-535 \mathrm{~cm}$, respectively (Nishizawa 1982). Generally speaking, our results on human ages agree with those of the charcoals, although these previous data have not been corrected for fractionation. Furthermore, this study showed that human individuals were buried within a shorter time frame between $8260 \pm 100 \mathrm{BP}$ and $8580 \pm 100 \mathrm{BP}$. In the case of human remains, the ${ }^{14} \mathrm{C}$ reservoir effect should be considered, because they might have exploited organisms derived from a ${ }^{14} \mathrm{C}$-depleted carbon source, such as seafood (Arneborg et al. 1999; Yoneda et al. 2000, 2001). In the case of coastal Jomon, the marine reservoir effect clearly altered the ${ }^{14} \mathrm{C}$ ages of human remains (Yoneda et al. 2002). However, this effect is negligible for the Tochibara samples since the stable isotopic analyses showed their collagen was originated primarily from terrestrial foods.

Calibration ages in this paper were calculated using the INTCAL98 calibration curve (Stuiver et al. 1998) with the OxCal ver. 3.0 calibration program (Bronk Ramsey 1995). Table 3 shows the calibrated ages of each sample. The calibrated determinations place the skeletons between $9100 \mathrm{cal}$ BP to $9690 \mathrm{cal}$ BP. Some of them show larger uncertainties because the calibration curve turned horizontal at the ranges.

Then, Bayesian methodology was employed for analyzing the series of ${ }^{14} \mathrm{C}$ dates (Bronk Ramsey 1995; Buck et al. 1996). If the six ${ }^{14} \mathrm{C}$ determinations were derived from one phase of human occupation as mentioned in the results, we can calculate the beginning and ending periods of the phase. It is estimated that the series of burials was initiated between 9610 and $9450 \mathrm{cal} \mathrm{BP}$ and terminated between 9460 and $9240 \mathrm{cal}$ BP. If more detailed information on their sequence was available, then the calibrated age of each sample could be confined more precisely by using Bayesian methods. 
Regarding the subsistence of the Tochibara people, the isotopic reconstruction seems to be consistent with archaeological evidence. Faunal remains contained many kinds of mammals, birds, finfish, and shellfish (Nishizawa 1982). Most frequent mammal species reported were Japanese deer (Cervus nippon) and Japanese wild boar (Sus leucomystax). Fish remains contained marine, brackish, and freshwater species including northern salmon, pacific abalone (Nordotis discus discus), freshwater pearly mussel (Margaritifera laevis), and estuary clam (Corbicula japonica). Our results showed that a small amount of seafood might be exploited but was almost negligible. It means that the seasonal migration to coastal area and/or the trading of foodstuffs with coastal populations was not common for the Tochibara Jomon people.

In Nagano, carbon isotope data showed that this dietary pattern of depending on terrestrial protein continued to the later Yayoi, Kofun, and Medieval periods (Yoneda et al. 1996). The Middle Jomon population from the Kitamura site (ca. $4500 \mathrm{BP}$ ) showed similar isotopic results, while the recent Edo (AD 16C) people exploited some amount of seafood (Figure 4). Kitamura Middle Jomon did not show correlation between two isotopic values, but a wider distribution of $\delta^{13} \mathrm{C}$ values. On the other hand, some archaeologists have suggested that the large settlements in the Middle Jomon period were sustained by the $\mathrm{C}_{4}$ millet agriculture (Fujimoto 1970). It might be possible to interpret that the wider $\delta^{13} \mathrm{C}$ variation in the Kitamura was influenced by $\mathrm{C}_{4}$ plants as a new nutritional resource. However, the differences in $\delta^{13} \mathrm{C}$ values were not clear between the Tochibara and Kitamura sites, and do not support the hypothesis that $\mathrm{C}_{4}$ millets were cultivated as a staple food item.

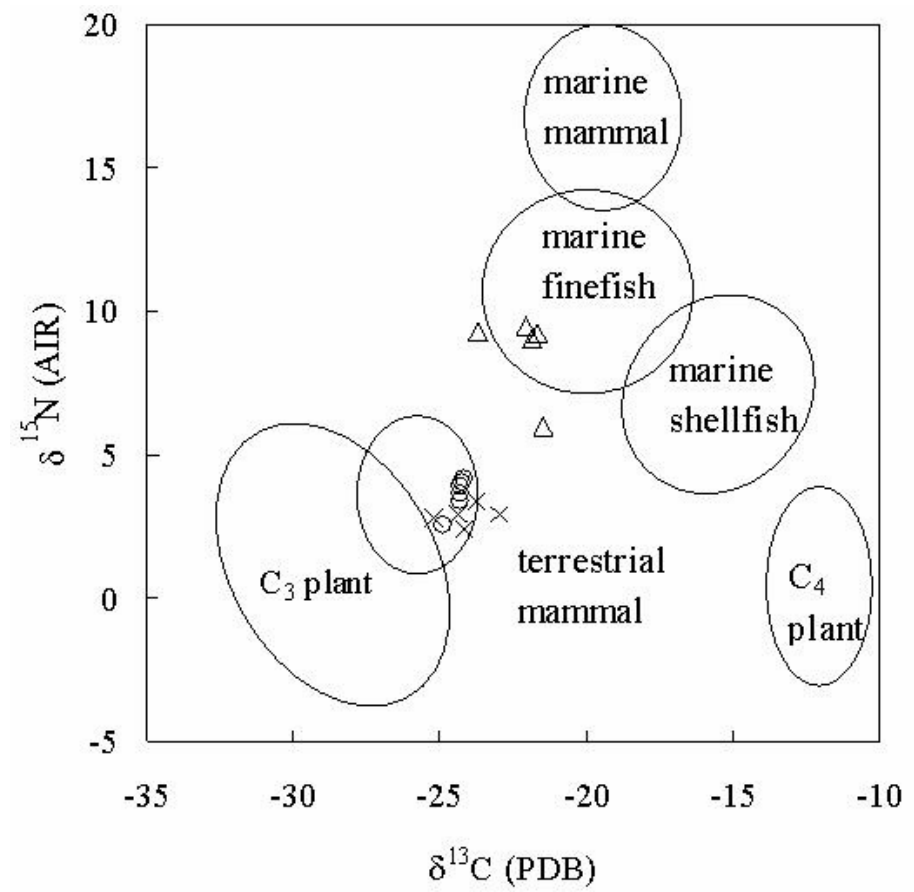

Figure 4 Comparison of dietary habits in Nagano between the Earliest Jomon (Tochibara), the Middle Jomon (Kitamura), and Edo (Hodokubo and Tsuchiya). Tochibara, Kitamura, and Edo people are shown as open circles, cross symbols, and triangles, respectively. 


\section{CONCLUSIONS}

Six human skeletons excavated from the Tochibara rockshelter were measured for ${ }^{14} \mathrm{C}$ dating and stable isotope analyses. ${ }^{14} \mathrm{C}$ dating indicated that these human skeletons date to the Earliest Jomon period and they are provided as one of rare examples of the oldest skeletal specimens from the inland of Japan. Bayesian statistics suggest that they were buried within shorter time period than suggested by a previous study. This skeletal collection should be re-evaluated from the morphological point of view to understand the structure of the Jomon people and the origin of modern Japanese.

At the same time, the isotopic results indicated that they might have exploited a small amount of seafood, but most of protein in their bodies was derived from the terrestrial ecosystem based on $\mathrm{C}_{3}$ plants. This is different from the dietary habit of coastal Jomon people who exploited both terrestrial and marine foodstuff substantially (Minagawa and Akazawa 1992). When their morphological characters are to be discussed, this discordance in dietary habits may explain the morphology of inland Japanese.

\section{ACKNOWLEDGMENTS}

Dr Y Kohara and Dr T Nishizawa kindly helped us to collect samples. Dr M E Hall of the Niigata Prefectural Museum of History kindly gave useful comments on draft paper and corrected the language thoroughly. Dr K Kigoshi provided information on previous measurements. Anonymous reviewers' comments were useful to improve this paper. The authors also thank Dr H Sekiguchi, $\mathrm{Mr}$ C Kobayashi, and Mr T Kobayashi for their assistance in AMS operation and Ms T Kitazaki and Ms S Minoura for their assistance in pretreatments. This study was supported in part by Grant-in-aid for Scientific Research (09740652) from the Ministry of Education, Science, Sports and Culture, Japan.

\section{REFERENCES}

Ambrose SH. 1993. Isotopic analysis of paleodiet: methodological and interpretive considerations. In: Sandford MK, editor. Investigations of ancient human tissue: chemical analyses in anthropology. Langhorne: Gordon and Breach. p 59-130.

Arneborg J, Heinemeier J, Lynnerup N, Nielsen HL, Rud N, Sveinbjörnsdóttir ÁE. 1999. Change of diet of the Greenland Vikings determined from stable carbon isotope analysis and ${ }^{14} \mathrm{C}$ dating of their bones. Radiocarbon 41(2):157-68.

Bronk Ramsey C. 1995. Radiocarbon calibration and analysis of stratigraphy: the program OxCal. Radiocarbon 37(2):425-30.

Buck CE, Cavanagh WG, Litton CD. 1996. Bayesian approach to interpreting archaeological data. Chicheser: John Wiley. 382 p.

DeNiro MJ. 1985. Postmortem preservation and alteration of in vivo bone collagen isotope ratios in relation to palaeodietary reconstruction. Nature 317: 806-9.

Fujimoto E. 1970. Jomon agriculture. Tokyo: Gakuseisha. 214 p.

Kawasaki T. 1997. Regarding age determination on sites in Nagano prefecture: comparison and usage of relative age and scientific dating methods. Journal of Archaeological Society of Nagano Prefecture 83:1-23. In Japanese.
Kitagawa H, Masuzawa T, Nakamura T, Matsumoto E. 1993. A batch preparation method for graphite targets with low background for AMS ${ }^{14} \mathrm{C}$ measurements. $R a$ diocarbon 35(1):295-300.

Kohara Y, Nakamura T, Nishizawa T, Suzuki M. 1971. Human infant remains of the Earliest Jomon period, suffering death by a falling rock. Journal of Anthropological Society of Nippon 79(1):55-60. In Japanese with English summary.

Longin R. 1971. New method of collagen extraction for radiocarbon dating. Nature 230:241-2.

Minagawa M, Akazawa, T. 1992. Dietary patterns of Japanese Jomon hunter- gatherers: stable nitrogen and carbon isotope analyses of human bones. In: Aikens CM, Rhee SN, editors. Pacific Northeast Asia in prehistory: recent research into the emergence of huntefisher-gatheres, farmers, and socio-political elites. Seattle: University Washington Press. p 59-67.

Minami H. 1995. Biogeochemical and ecological studies of 4 species of Procellariidae (Puffinus) in the North Pacific using stable carbon and nitrogen isotope analysis: [dissertation] Sapporo (Japan): Hokkaido University. 155 p. In Japanese with English summary.

Nishizawa T. 1978. Human skeletons from the Tochibara rockshelter site: its burial pattern and physical characters. In: [AANP] Archaeological Association of Na- 
gano Prefecture, editor. Archaeology of the Central Height. Nagano: Archaeological Association of $\mathrm{Na}-$ gano Prefecture. p 94-104. In Japanese.

Nishizawa T. 1982. The Tochihara rockshelter site. In: Nagano Prefecture, editor. History of Nagano Prefecture (Nagano kenshi), archaeological material 1(2): main sites (northern and eastern Shinshu). Nagano: Nagano prefecture. p 559-84. In Japanese.

Oomi Y, editor. 1984. Excavation report of the Tochibara Rockshelter site in 1983. Matsumoto: Shinshu University. p 82. In Japanese.

Schwarcz HP. 1991. Some theoretical aspects of isotope paleodiet studies. Journal of Archaeological Science 18:261-75.

Shimojo H. 1988. Basic research for the dietary reconstruction of the Okadaira shell midden inhabitant based on carbon and nitrogen stable isotopic ratios [master's thesis]. Tokyo (Japan): University of Tokyo. 71 p. In Japanese.

Stuiver M, Reimer PJ, Bard E, Beck JW, Burr GS, Hughen KA, Kromer B, McCormac G, van der Plicht J, Spurk M. 1998. INTCAL98 radiocarbon age calibration, 24,000-0 cal BP. Radiocarbon 40(3):104183.

Tanaka A, Yoneda M, Uchida M, Uehiro T, Shibata Y, Morita M. 2000. Recent advances in ${ }^{14} \mathrm{C}$ measurement at NIES-TERRA. Nuclear Instruments and Methods in Physics Research B 172:107-11.

Welch DW, Parsons TR. $1993 . \delta^{13} \mathrm{C}-\delta^{15} \mathrm{~N}$ values as indicators of trophic position and competitive overlap for Pacific salmon (Oncorhynchus spp.). Fisheries Oceanography 2:11-23.

Yoneda, M, Yoshida K, Yoshinaga J, Morita M, Akazawa T. 1996. Reconstruction of palaeodiet in Nagano Prefecture based on the carbon and nitrogen isotope analysis and the trace elemental analysis. The Quaternary Research (Daiyonki-kenkyu) 35(4):293-303. In Japanese with English summary.

Yoneda M, Kitagawa H, van der Plichit J, Uchida M, Tanaka A, Uehiro T, Shibata Y, Morita M, Ohno T. 2000. Pre-bomb marine reservoir ages in the western North Pacific: preliminary result on Kyoto University collection. Nuclear Instruments and Methods in Physics Research B 172:377-81.

Yoneda M, Hirota M, Uchida M, Uzawa K, Tanaka A, Shibata Y, Morita M. 2001. Marine radiocarbon reservoir effect in the western North Pacific observed in archaeological fauna. Radiocarbon 43(2A):465-71.

Yoneda M, Uzawa K, Hirota M, Uchida M, Tanaka A, Shibata Y, Morita M. 2002. Radiocarbon marine reservoir effect in human remains from the Kitakogane site, Hokkaido, Japan. Journal of Archaeological Science 29(5):529-36. 